\title{
Production and Characterization of Monoclonal Antibodies against Human Pancreatic Phospholipase $\mathbf{A}_{2}$
}

\author{
Atsushi MisaKI, ${ }^{*}$ Misao IDE, and Masao Kono \\ Shionogi Research Laboratories, Shionogi \& Co., Ltd., Fukushima-ku, Osaka 553, Japan
}

(Received April 6, 1991)

\begin{abstract}
Summary Five hybridoma cell lines producing monoclonal antibodies against human pancreatic phospholipase $\mathrm{A}_{2}\left(\mathrm{PLA}_{2}\right)$ were established after selection from prepared hybridomas on the basis of the affinity of the antibodies they produced. All the monoclonal antibodies $(1008,1015,1045,1085$, and 2003$)$ proved to have very high affinity toward human pancreatic $\mathrm{PLA}_{2}\left(K_{\mathrm{a}}=1.5 \times 10^{11}-1.2 \times 10^{12} \mathrm{M}^{-1}\right)$, but to have no cross reactivity with porcine pancreatic $\mathrm{PLA}_{2}$, snake venom $\mathrm{PLA}_{2}$, and membrane-associated $\mathrm{PLA}_{2}$ from human spleen. Cross reactivities with human pancreatic prophospholipase $\mathrm{A}_{2}$ (proPLA $\mathrm{A}_{2}$ ) ranged from 4 to $49 \%$. Three of the monoclonal antibodies neutralized the enzyme activity of $\mathrm{PLA}_{2}$, while the other two had no effect on it. The three neutralizing antibodies had smaller cross reactivities with proPLA than the other two. On radioimmunoassay using these monoclonal antibodies, the $\mathrm{PLA}_{2}$ contents of sera from patients with acute pancreatitis were above normal in every case. These monoclonal antibodies are expected to be useful tools in the diagnosis of acute pancreatitis.
\end{abstract}

Key Words: human pancreatic phospholipase $\mathrm{A}_{2}$, monoclonal antibody, radioimmunoassay, cross reactivity, acute pancreatitis

Human pancreatic phospholipase $\mathrm{A}_{2}\left(\mathrm{PLA}_{2}\right.$; EC 3.1.1.4) is a digestive enzyme synthesized by pancreatic acinar cells as an enzymatically inactive prophospholipase $\mathrm{A}_{2}$ (proPLA $\mathrm{A}_{2}$ ), which is secreted into the duodenum and converted to the active form by tryptic cleavage of a seven-amino acid peptide from the $\mathrm{N}$-terminus. The importance of $\mathrm{PLA}_{2}$ in the development and aggravation of acute pancreatitis has been discussed [1-3], and the elevation of $\mathrm{PLA}_{2}$ activity in the sera from patients with acute pancreatitis has been reported [4-7].

\footnotetext{
*To whom correspondence should be addressed.
} 
Serum $\mathrm{PLA}_{2}$ can be measured enzymologically or immunologically. Although several authors have reported the measurement of the enzyme activity of $\mathrm{PLA}_{2}$ in human sera [4-7], these methods require long incubation times because of the low $\mathrm{PLA}_{2}$ activity in the sera, and tedious procedures are needed for the extraction of the product of the enzyme reaction. These drawbacks make activity measurements difficult to apply to clinical use. The immunological method is expected to be more sensitive, convenient and accurate than the enzymological method, and moreover, is able to detect the enzyme as the whole enzyme molecule, including those that have no enzyme activity. Radioimmunoassay (RIA) and time-resolved fluoroimmunoassay of human pancreatic $\mathrm{PLA}_{2}$ using polyclonal antibodies (pAbs) have been reported $[8,9]$, and these methods show significant elevations of serum $\mathrm{PLA}_{2}$ levels in patients with acute pancreatitis.

We describe here the development of monoclonal antibodies (mAbs) against human pancreatic $\mathrm{PLA}_{2}$, which were found to have high affinity and specificity and which can be applied to clinical use.

\section{MATERIALS AND METHODS}

Materials. Porcine pancreatic $\mathrm{PLA}_{2}$ and fetal calf serum were purchased from Boehringer Mannheim GmbH (Germany); and Naja naja venom PLA $\mathrm{A}_{2}$ came from Sigma Chemical Co. (St. Louis, MO). RPMI 1640 Medium (autoclavable) was purchased from Nissui Pharmaceutical Co., Ltd. (Tokyo). Immunobead (rabbit anti-mouse immunoglobulin) was a product of Bio-Rad Laboratories (Richmond, CA). Other chemicals were of the highest grade available. Assay buffer for RIA was $0.01 \mathrm{M}$ PBS ( $\mathrm{pH} 7.4$ ) containing $1 \mathrm{mM}$ EDTA, $0.01 \% \mathrm{NaN}_{3}$ and $0.2 \%$ BSA.

Human pancreatic $P L A_{2}$ and proPLA $A_{2}$. Human pancreatic $\mathrm{PLA}_{2}$ was purified from pancreatic juice as described by Nishijima et al. [8]. Human pancreatic proPLA $\mathrm{A}_{2}$ was purified from the same according to Grataroli et al. [10], except that chromatography on CM-Sepharose was done twice. Both of them were found to be pure by amino acid analysis and SDS-PAGE. Pancreatic juice was kindly donated by Dr. M. Ogawa (Osaka University Medical School).

Serum samples. Sera from patients with acute pancreatitis were kindly donated by Dr. M. Ogawa (Osaka University Medical School). The diagnosis of acute pancreatitis had been made by him based on the following criteria: (a) the clinical condition and its evolution; (b) the elevated amylase activity in serum and/or urine; (c) the results of computed tomography and/or laparotomy.

Enzymatic assay of $P L A_{2}$. The enzyme activity of $\mathrm{PLA}_{2}$ was measured according to the method described by Katsumata et al. [11], except that L- $\alpha$ phosphatidylcholine, 1-palmitoyl-2- $\left[1-{ }^{14} \mathrm{C}\right]$ palmitoyl (Amersham Japan, Tokyo) was used instead of a ${ }^{3} \mathrm{H}$-labelled substrate, and the volume of the enzyme reaction was reduced to one tenth. The enzyme reaction was run for $1 \mathrm{~h}$ at $37^{\circ} \mathrm{C}$ and terminated by addition of $20 \mu 1$ of $5 \%$ Triton X-100 containing $0.2 \mathrm{M}$ EDTA. The 
product of the enzyme reaction was extracted with $750 \mu 1$ of hexane containing $0.1 \%$ acetic acid after addition of approximately $500 \mathrm{mg}$ of anhydrous $\mathrm{Na}_{2} \mathrm{SO}_{4}$. The radioactivity in $500 \mu 1$ of the hexane layer was determined by liquid scintillation counting.

Preparation of mAbs. Human pancreatic $\mathrm{PLA}_{2}$ dissolved in saline was emulsified with Freund's complete adjuvant and administered subcutaneously to female BALB/c mice three times at three-week intervals. The administered dose of $\mathrm{PLA}_{2}$ each time was $25 \mu \mathrm{g}$ for fusion 1 and $5 \mu \mathrm{g}$ for fusion 2. PLA $\mathrm{P}_{2}$ solution in saline (50 $\mu \mathrm{g}$ for fusion 1 and $10 \mu \mathrm{g}$ for fusion 2) was injected intraperitoneally into the mice with the highest anti-PLA $\mathrm{P}_{2}$ titer three days before the cell fusion.

The fusion procedure was based on the method of Galfrè and Milstein [12]. Spleen cells from immunized mouse were fused with P3-NS1/1-Ag4 mouse myeloma cells in the presence of 50\% polyethylene glycol (MW4,000, Merck). Cells were then suspended in HAT (hypoxanthine, aminopterin, and thymidine) medium and seeded into wells of 96-well culture plates.

All wells containing hybridomas were screened for antibodies to human pancreatic $\mathrm{PLA}_{2}$ by the enzyme-linked immunosorbent assay (ELISA) described below. Hybridomas in positive wells were allowed to expand in about $10 \mathrm{ml}$ of culture medium and then frozen. Culture supernatants collected at that time were subjected to the displacement test (see below). Hybridomas selected by this test were cloned by limiting dilution.

ELISA. In this assay, 96-well microtiter plates (Nunc-Immuno Plate, Nunc, Roskilde, Denmark) were coated with human pancreatic PLA $\mathrm{PL}_{2}$ by addition of 50 $\mu 1$ of $\mathrm{PLA}_{2}$ solution $(200 \mathrm{ng} / \mathrm{ml}$ in $0.05 \mathrm{M}$ carbonate buffer, $\mathrm{pH} 8.5)$ to each well and incubation of the plates overnight at $4^{\circ} \mathrm{C}$. The wells were blocked with $0.2 \%$ BSA-PBS and washed with $0.5 \%$ Tween 80 -PBS. Next, $50 \mu 1$ of each hybridoma supernatant was added to a $\mathrm{PLA}_{2}$-coated well, and the plates were incubated for $1 \mathrm{~h}$ at $37^{\circ} \mathrm{C}$. Antibodies bound to the wells were detected by a commercial kit utilizing biotinylated anti-mouse IgG and avidin-biotinylated peroxidase complex (Vectastain ABC kit, Vector Laboratories, Burlingame, CA) with ABTS as the coloring agent.

Radioiodination of human pancreatic $P L A_{2}$. A 5- $\mu$ g sample of human pancreatic $\mathrm{PLA}_{2}$ was radioiodinated with $18.5 \mathrm{MBq}$ of $\mathrm{Na}^{125}$ I by the chloramine- $\mathrm{T}$ method [13]. ${ }^{125}$ I-Human pancreatic PLA $_{2}$ was separated from free ${ }^{125} \mathrm{I}^{-}$by gel filtration on a Sephadex G-25 column $(1 \times 25 \mathrm{~cm})$. The specific activity of ${ }^{125} \mathrm{I}$ human pancreatic $\mathrm{PLA}_{2}$ was $2.6-3.0 \mathrm{MBq} / \mu \mathrm{g}$.

Displacement test of culture supernatants. This test was done to estimate which of the frozen hybridomas produced antibody of high affinity. Serial dilutions of culture supernatants $(100 \mu 1)$ were mixed with $100 \mu 1$ of ${ }^{125}$ I-human pancreatic $\mathrm{PLA}_{2}(40,000 \mathrm{cpm})$ and $100 \mu 1$ of $2 \%$ bovine $\gamma$-globulin dissolved in assay buffer ( $\gamma$-globulin buffer) and incubated overnight at room temperature. B/ F separation was performed by the polyethylene glycol method. The same procedure was done by addition of human pancreatic PLA $_{2}(50 \mathrm{ng} / \mathrm{ml})$ in $\gamma$-globulin 
buffer in place of $\gamma$-globulin buffer, and the decrease of radioactivity in the bound fraction was examined.

RIA. A $100-\mu 1$ sample of human pancreatic $\mathrm{PLA}_{2}$ standard solution or sample, $100 \mu 1$ of ${ }^{125}$ I-human pancreatic $\mathrm{PLA}_{2}(40,000 \mathrm{cpm}), 100 \mu 1$ of diluted ascites, and $200 \mu 1$ of assay buffer were mixed in disposable polystyrene tubes and incubated overnight at room temperature. One hundred microliters of Immunobead (rabbit anti-mouse immunoglobulin, $1 \mathrm{mg} / \mathrm{ml}$ assay buffer) was then added; and after $1 \mathrm{~h}$ at room temperature, the tubes were centrifuged $(2,000 \times g, 5$ $\min )$. The supernatant was removed, and the radioactivity of the pellet was measured.

\section{RESULTS}

\section{Preparation of $m A b s$}

Two fusions were performed. Hybridoma cell colonies appeared in 508 wells for fusion 1 and in 471 wells for fusion 2. In fusion 1, more than 200 wells were initially positive by ELISA. Although some of them became negative during successive culture, we froze hybridomas from 85 wells while they were positive. In fusion 2, the number of initially positive wells was 52, and the cells from 24 of them were frozen.

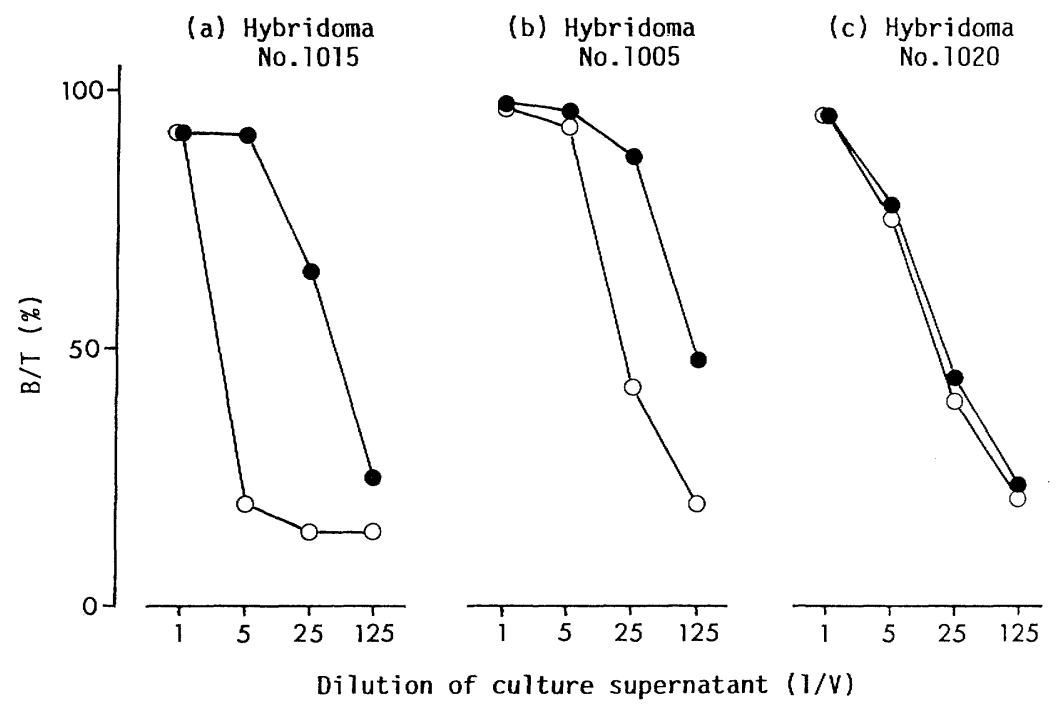

Fig. 1. Displacement test of the hybridoma culture supernatants. Dilution curves of the culture supernatants collected at the time of hybridoma freezing were prepared by RIA using ${ }^{125}$ I-human pancreatic PLA PL $_{2}$ in the absence $(\bullet)$ or presence $(O)$ of $5 \mathrm{ng} /$ tube of human pancreatic PLA $\mathrm{P}_{2}$. Out of the total of 109 samples, results for three culture supernatants which showed (a) large, (b) moderate, or (c) little displacement are shown as examples. 
Culture supernatants collected at the time of hybridoma freezing were subjected to the displacement test. We found that there were great differences in the degree of displacement among the supernatants. Figure 1 shows, for example, the results of the displacement test for three culture supernatants: they showed large, moderate, or little displacement.

Our main aim in this study was to develop an immunoassay for human pancreatic PLA $\mathrm{P}_{2}$. The sensitivity of the immunoassay is greatly influenced by the affinity of the antibody used in the assay system. We considered that hybridomas showing large displacement in the displacement test produced antibodies of high affinity; and from this point of view, we selected five hybridomas, which were then established by cloning.

Thus, we obtained five hybridoma cell lines: 1008, 1015, 1045, and 1085 from fusion 1, and 2003 from fusion 2. Ascitic fluids were prepared for each of these hybridomas, and the properties of the $\mathrm{mAbs}$ in these ascites were studied. IgG was purified from the ascites by use of a protein A column (Bio-Rad MAPS kits), if necessary.

\section{Immunoglobulin class and affinity constants}

All five $\mathrm{mAbs}$ were $\mathrm{IgG}_{1}$ and had $\varkappa$ light chains as determined by ELISA using a Mouse Mono Ab-ID EIA kit (ZYMED Laboratories, San Francisco, CA).

The affinity constants calculated from the Scatchard plots [14] are shown in Table 1 . They ranged from $1.5 \times 10^{11} \mathrm{M}^{-1}$ for 1045 to $1.2 \times 10^{12} \mathrm{M}^{-1}$ for 1085 . Thus, all of these hybridoma cell lines produced $\mathrm{mAbs}$ of very high affinity for human pancreatic PLA .

\section{Standard curves of RIA}

Standard curves for human pancreatic $\mathrm{PLA}_{2}$ were prepared for RIA using five mAbs. Dilutions of ascites were from $1: 360,000$ for 1008 to $1: 800,000$ for 1085 , which made the $B_{0} / T$ approximately $40 \%$. The $90 \%$ intercept values of the standard curves were as follows: with $1008,0.4 \mathrm{ng} / \mathrm{ml}$; with $1015,0.4 \mathrm{ng} / \mathrm{ml}$; with 1045 , $0.5 \mathrm{ng} / \mathrm{ml}$; with $1085,0.3 \mathrm{ng} / \mathrm{ml}$; and with 2003, $0.4 \mathrm{ng} / \mathrm{ml}$. Figure 2 shows the standard curve obtained with mAb 1085. Human pancreatic $\mathrm{PLA}_{2}$ could be measured with good sensitivity by RIA using any of the five mAbs.

Table 1. Properties of mAbs.

\begin{tabular}{ccc}
\hline $\mathrm{mAb}$ & $K_{\mathrm{a}}\left(\mathrm{M}^{-1}\right)$ & $\begin{array}{c}\text { Cross reactivity (\%) with } \\
\text { human pancreatic proPLA }\end{array}$ \\
\hline 1008 & $4.1 \times 10^{11}$ & 49 \\
1015 & $1.0 \times 10^{12}$ & 4 \\
1045 & $1.5 \times 10^{11}$ & 39 \\
1085 & $1.2 \times 10^{12}$ & 19 \\
2003 & $3.9 \times 10^{11}$ & 7 \\
\hline
\end{tabular}

Vol. 11, No. 2, 1991 


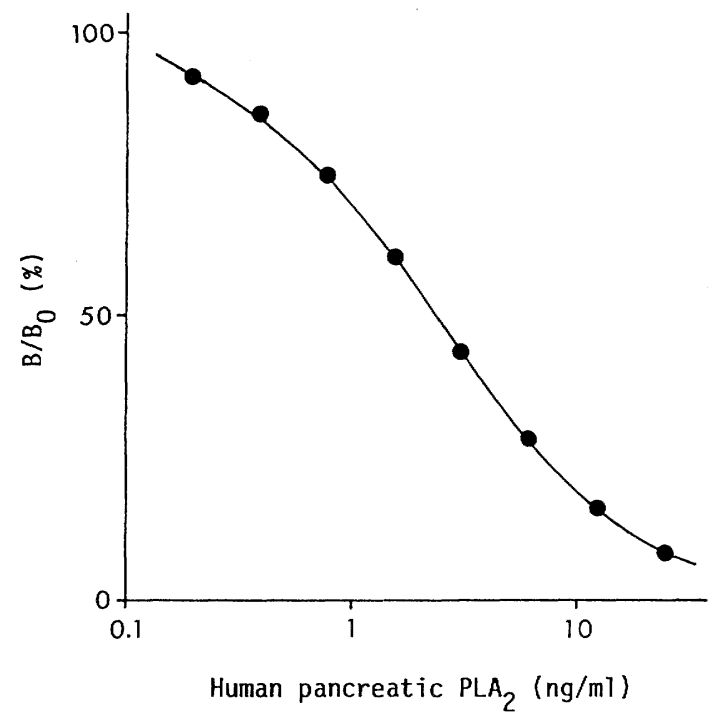

Fig. 2. Standard curve of the RIA for human pancreatic PLA $A_{2}$ using mAb 1085. Similar curves were obtained for the other four mAbs with some differences in the sensitivity. The conditions of the assay were as described in Materials and Methods.

Cross reactivity with other $P L A_{2} S$

No detectable decrease in the radioactivity of the bound fraction was observed in the RIA using any of the five mAbs by addition of porcine pancreatic $\mathrm{PLA}_{2}$ (up to $5 \mu \mathrm{g} / \mathrm{ml}$ ), Naja naja venom $\mathrm{PLA}_{2}$ (up to $5 \mu \mathrm{g} / \mathrm{ml}$ ), or membrane-associated PLA $_{2}$ from human spleen (up to $2 \mu \mathrm{g} / \mathrm{ml}$ ) that had been purified in our laboratory [15]. These concentrations were more than or nearly 1,000 times the concentration of human pancreatic PLA $\mathrm{PL}_{2}$ exhibiting a $50 \%$ intercept on the standard curve. Therefore, our mAbs do not cross-react with these three kinds of PLA 2 .

Cross reactivity with human pancreatic proPL $A_{2}$

All the $\mathrm{mAbs}$ gave standard curves for human pancreatic proPLA $\mathrm{A}_{2}$ parallel to the curve for human pancreatic $\mathrm{PLA}_{2}$ on RIA. Cross reactivities with human pancreatic proPLA $\mathrm{A}_{2}$ calculated from the $50 \%$ intercept of both standard curves are shown in Table 1 . They varied from $4 \%$ for 1015 to $49 \%$ for 1008 , suggesting differences in binding sites among the mAbs.

\section{Effect on PLA $A_{2}$ enzyme activity}

As shown in Fig. 3, the mAbs could be divided into two groups: 1015, 1085, and 2003, which completely neutralized the enzyme activity of human pancreatic $\mathrm{PLA}_{2}$, and 1008 and 1045, which had little effect on it. The amount of the neutralized enzyme agreed fairly well with that of the enzyme to which bivalent IgG would bind, which assures that this neutralizing effect is a specific one. Also, the former group of $\mathrm{mAbs}$ (neutralizing $\mathrm{mAbs}$ ) was found to have smaller cross 


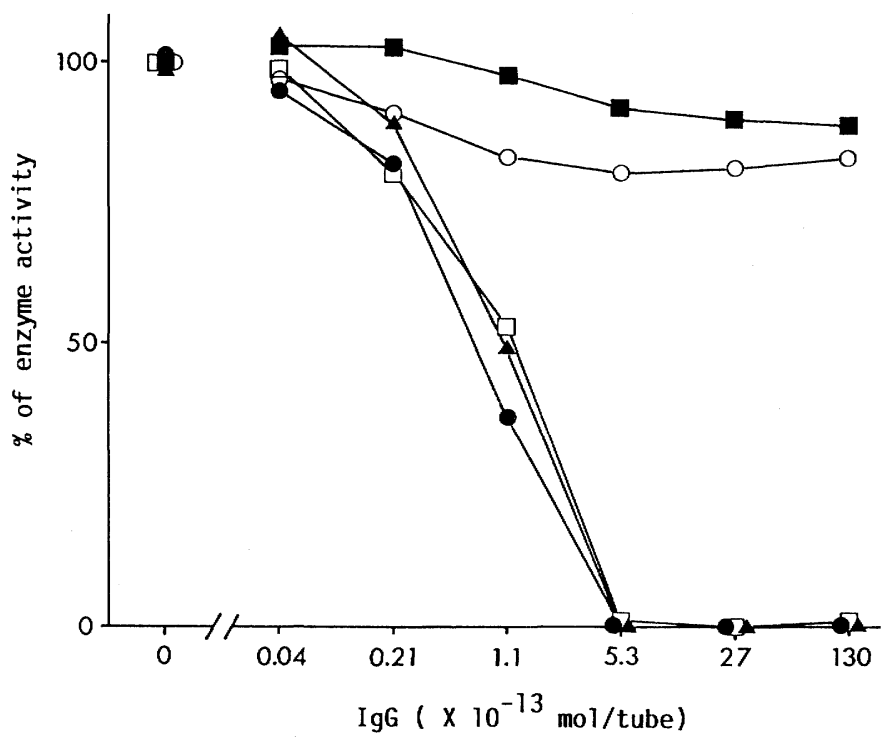

Fig. 3. Effect of the mAbs on the enzyme activity of PLA $\mathrm{A}_{2}$. Constant amounts $\left(3.6 \times 10^{-13}\right.$ $\mathrm{mol} /$ tube) of human pancreatic PLA $\mathrm{A}_{2}$ and serial dilutions of the purified IgG solution of mAb $1008(\square), 1015(\square), 1045(\bigcirc), 1085(\bullet)$, or $2003(\triangle)$ were mixed and incubation was done for $1 \mathrm{~h}$ at $37^{\circ} \mathrm{C}$. After that, the enzyme activity of PLA $A_{2}$ in the mixture was measured as described in Materials and Methods. The values are presented as a percent of the enzyme activity found in the absence of antibody.

Table 2. Within- and between-assay variations of RIA using mAb 1008 .

\begin{tabular}{cccc}
\hline Assay & $\begin{array}{c}\text { Number of } \\
\text { determinations }\end{array}$ & $\begin{array}{c}\text { Mean } \pm \mathrm{SD} \\
(\mathrm{ng} / \mathrm{ml})\end{array}$ & $\begin{array}{c}\text { Coefficient of } \\
\text { variation (\%) }\end{array}$ \\
\hline Within-assay & & & \\
Serum 1 & 6 & $2.45 \pm 0.08$ & 3.3 \\
Serum 2 & 6 & $8.60 \pm 0.16$ & 1.9 \\
Serum 3 & 6 & $22.87 \pm 1.11$ & 4.9 \\
\hline Between-assay & & & \\
Serum 1 & 5 & $2.43 \pm 0.08$ & 3.2 \\
Serum 2 & 5 & $8.46 \pm 0.27$ & 3.2 \\
Serum 3 & 5 & $23.21 \pm 0.96$ & 4.1 \\
\hline
\end{tabular}

reactivities with human pancreatic proPLA $\mathrm{A}_{2}$ while the latter (non-neutralizing $\mathrm{mAbs}$ ) had larger cross reactivities (see Table 1).

\section{Reproducibility}

Reproducibility of the RIA was estimated with human sera having different $\mathrm{PLA}_{2}$ levels. On RIA using mAb 1008, the coefficients of variation for within- and between-assay series were $1.9-4.9 \%(n=6)$ and $3.2-4.1 \%(n=5)$, respectively, as shown in Table 2 . Other four mAbs also gave values below $10 \%$. 


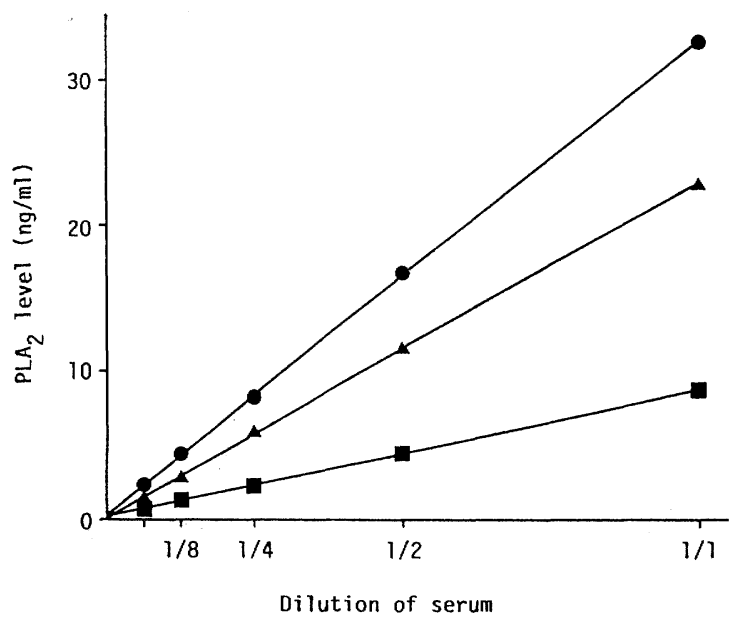

Fig. 4. Dilution test of human sera. Three serum samples having different $\mathrm{PLA}_{2}$ levels were diluted serially with assay buffer, then measured by the RIA using mAb 1008 .
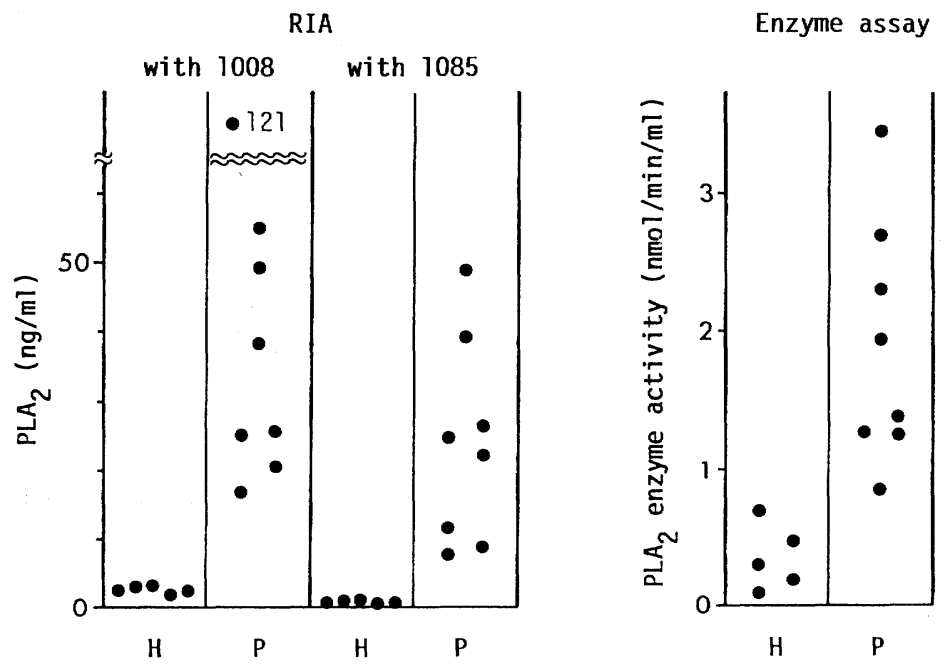

Fig. 5. Serum levels of $\mathrm{PLA}_{2}$ in healthy individuals $(\mathrm{H})$ and patients with acute pancreatitis $(\mathrm{P})$. Human pancreatic $\mathrm{PLA}_{2}$ contents were measured by the RIA using $\mathrm{mAb}$ 1008 and 1085 , and PLA $_{2}$ enzyme activities were measured by the enzyme assay described by Isaji [16], for the same serum groups. 


\section{Dilution test of serum}

Serial-dilution experiments of human sera gave linear lines that passed through the origin when any of the five mAbs was used for the RIA. Figure 4 shows the result for an RIA using mAb 1008.

\section{Serum level}

The average $\mathrm{PLA}_{2}$ levels (mean $\pm \mathrm{SD}, \mathrm{ng} / \mathrm{ml}$ ) of sera from five healthy individuals measured by RIA using each of the five mAbs were the following: with 1008, $3.1 \pm 0.8$; with $1015,0.6 \pm 0.1$; with $1045,2.4 \pm 0.5$; with $1085,1.3 \pm 0.2$; and with $2003,0.7 \pm 0.2$. Significant differences in the measured values among the $m A b s$ were observed, and those that had larger cross reactivities with proPLA $\mathrm{P}_{2}$ gave higher serum levels (see Table 1).

$\mathrm{PLA}_{2}$ contents in sera from five healthy individuals and eight patients with acute pancreatitis measured by RIA using mAb 1008 and 1085 are shown in Fig. 5. $\mathrm{PLA}_{2}$ enzyme activities in these sera measured by the enzyme assay described by Isaji [16] are also shown in this figure. In all cases of patients with acute pancreatitis, serum levels were above the normal range with both RIAs. Enzyme activities of $\mathrm{PLA}_{2}$ in sera from patients with acute pancreatitis were also above normal. However, the difference in the measured values between the two serum groups was more prominent on RIA than on enzyme assay.

\section{DISCUSSION}

In this study, we established five hybridoma cell lines producing mAbs against human pancreatic $\mathrm{PLA}_{2}$. All the mAbs were found to have very high affinity for human pancreatic $\mathrm{PLA}_{2}$, allowing highly sensitive radioimmunoassays to be developed. These mAbs were also highly specific for human pancreatic $\mathrm{PLA}_{2}$, having no cross reactivity with porcine pancreatic $\mathrm{PLA}_{2}$, snake venom PLA $\mathrm{P}_{2}$, and membrane-associated $\mathrm{PLA}_{2}$ from human spleen. These properties of the mAbs make them favorable as reagents in immunoassay systems for diagnostic purposes.

Hybridomas should be cloned as soon as possible after screening, but in this study, there were too many positive hybridomas to clone at one time. We therefore froze these positive hybridomas and selected by means of the displacement test those producing antibodies of high affinity. The selected hybridomas were then thawed and cloned. This method is considered to be effective when many wells are found to be positive in the first screening.

The mAbs were divided into two groups depending on their effect on the enzyme activity of human pancreatic $\mathrm{PLA}_{2}$ : those that completely neutralized the enzyme activity (neutralizing $\mathrm{mAbs}$ ) and those that had little effect on it (nonneutralizing mAbs). The $\mathrm{N}$-terminal region of $\mathrm{PLA}_{2}$ has been suggested to have an important role in the catalytic activity of the enzyme [17]. We found that the neutralizing $\mathrm{mAbs}$ had smaller cross reactivities with human pancreatic proPLA, 
which has an extra polypeptide sequence (seven amino acids) at the N-terminal of $\mathrm{PLA}_{2}$, while the non-neutralizing $\mathrm{mAbs}$ had larger cross reactivities. Although the conformational changes between proPLA ${ }_{2}$ and $\mathrm{PLA}_{2}$ should be taken into consideration, we assume that the binding sites of the $m A b s$ having smaller cross reactivities with proPLA $A_{2}$ are near the N-terminal of $\mathrm{PLA}_{2}$ and those of $\mathrm{mAbs}$ having larger cross reactivities with it are apart from the $\mathrm{N}$-terminal. Thus, in this respect, our results are in accord with the suggested relationship of the N-terminal region of $\mathrm{PLA}_{2}$ with the catalytic activity.

Our present RIA using the mAbs can determine the PLA $\mathrm{P}_{2}$ levels in human sera with good precision and accuracy. They clearly distinguished sera from healthy individuals and sera from patients with acute pancreatitis, with more prominent differences in the measured values between the two serum groups than found with the enzyme assay. This indicates that these mAbs can be useful tools in the diagnosis of acute pancreatitis.

The high specificity of the mAbs for human pancreatic PLA $\mathrm{A}_{2}$ allows the RIA using them to be unaffected by other $\mathrm{PLA}_{2}$ s. Especially, in the case of measurement of pancreatic $\mathrm{PLA}_{2}$ levels in human sera, interference by the membrane-associated $\mathrm{PLA}_{2}$ (type II PLA $\mathrm{PL}_{2}$ ) is thought to be an important concern. It may be detected by

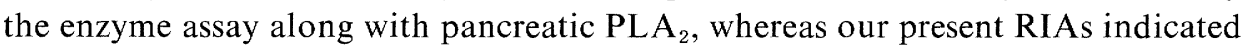
no cross reactivities with it. This feature is considered to make our RIAs suitable for the diagnosis of acute pancreatitis. Moreover, the high affinity of the mAbs may make it possible to develop a more rapid immunoassay system that would be favorable for clinical use.

Five mAbs gave different values for the same serum group from healthy individuals, and the relationship between the measured values and their cross reactivities with proPLA $\mathrm{A}_{2}$ has been pointed out. Supposing that there exist on the average about $5 \mathrm{ng} / \mathrm{ml}$ of proPLA $A_{2}$ and about $0.5 \mathrm{ng} / \mathrm{ml}$ of $\mathrm{PLA}_{2}$ in normal human sera, these serum levels given by the five $m A b s$ are reasonable. This suggests that pancreatic $\mathrm{PLA}_{2}$ mostly exists as the inactive proPLA $\mathrm{P}_{2}$ molecule in normal sera. Further investigations are described in the following report.

We are grateful to Dr. M. Ogawa (Osaka University Medical School) for his kind donation of human pancreatic juice and human serum samples.

\section{REFERENCES}

1. Schmidt, H., and Creutzfeldt, W. (1969): The possible role of phospholipase A in the pathogenesis of acute pancreatitis: Scand. J. Gastroenterol., 4, 39-48.

2. Creutzfeldt, W., and Schmidt, H. (1970): Aetiology and pathogenesis of pancreatitis (current concepts). Scand. J. Gastroenterol., 6, Suppl., 47-62.

3. Nevalainen, T.J. (1980): The role of phospholipase A in acute pancreatitis. Scand. J. Gastroenterol., 15, 641-650.

4. Zieve, L., and Vogel, W.C. (1961): Measurement of lecithinase A in serum and other body fluids. J. Lab. Clin. Med., 57, 586-599.

5. Doizaki, W.M., and Zieve, L. (1966): Turbidimetric serum phospholipase A activity in acute 
pancreatitis. J. Lab. Clin. Med., 67, 108-115.

6. Hashihira, S., Nishii, T., Takeda, Y., Mori, R., and Wakabayashi, A. (1977): Serum phospholipase A in patients with acute pancreatitis. Jpn. Arch. Intern. Med., 24, 243-249.

7. Schröder, T., Kivilaakso, E., Kinnunen, P.K.J., and Lempinen, M. (1980): Serum phospholipase $\mathrm{A}_{2}$ in human acute pancreatitis. Scand. J. Gastroenterol., 15, 633-636.

8. Nishijima, J., Okamoto, M., Ogawa, M., Kosaki, G., and Yamano, T. (1983): Purification and characterization of human pancreatic phospholipase $\mathrm{A}_{2}$ and development of a radioimmunoassay. J. Biochem., 94, 137-147.

9. Eskola, J.U., Nevalainen, T.J., and Lövgren, T.N.E. (1983): Time-resolved fluoroimmunoassay of human pancreatic phospholipase $\mathrm{A}_{2}$. Clin. Chem., 29, 1777-1780.

10. Grataroli, R., De Caro, A., Guy, O., Amic, J., and Figarella, C. (1981): Isolation and properties of prophospholipase $\mathrm{A}_{2}$ from human pancreatic juice. Biochimie, 63, 677-684.

11. Katsumata, M., Gupta, C., and Goldman, A.S. (1986): A rapid assay for activity of phospholipase $\mathrm{A}_{2}$ using radioactive substrate. Anal. Biochem., 154, 676-681.

12. Galfrè, G., and Milstein, C. (1981): Preparation of monoclonal antibodies: Strategies and procedures. Methods Enzymol., 73, 3-46.

13. Hunter, W.M., and Greenwood, F.C. (1962): Preparation of iodine-131 labelled human growth hormone of high specific activity. Nature, 194, 495-496.

14. Scatchard, G. (1949): The attractions of proteins for small molecules and ions. Ann. NY. Acad. Sci., 51, 660-672.

15. Kanda, A., Ono, T., Yoshida, N., Tojo, H., and Okamoto, M. (1989): The primary structure of a membrane-associated phospholipase $\mathrm{A}_{2}$ from human spleen. Biochem. Biophys. Res. Commun., 163, 42-48.

16. Isaji, S. (1985): Pathogenesis of fat necrosis in acute pancreatitis, with special reference to the role of pancreatic phospholipase $\mathrm{A}_{2}$. Mie Med. J., 35, 109-123.

17. Van Scharrenburg, G.J.M., Jansen, E.H.J.M., Egmond, M.R., De Haas, G.H., and Slotboom, A.J. (1984): Structural importance of the amino-terminal residue of pancreatic phospholipase $\mathrm{A}_{2}$. Biochemistry, 23, 6285-6294. 